Henryk KOWALSKI

(Lublin, UMCS)

\title{
SPOKÓJ CZY SMUTEK? KONCEPCJA STAROŚCI W PISMACH MARKA TULLIUSZA CYCERONA
}

Badania nad różnymi problemami życia ludzi starszych w starożytnym Rzymie mająjuż dość długą historię ${ }^{1}$. Jej rezultatem jest wiele prac poruszających medyczne, psychologiczne, społeczne, polityczne, religijne i kulturowe aspekty starości ${ }^{2}$. Jednym z zagadnień wzbudzających zainteresowanie współczesnych badaczy są poglądy filozoficzne starożytnych autorów oraz odzwierciedlenie tej problematyki w literaturze antycznej ${ }^{3}$.

„Czym jest starość? Czasem mówi się o niej jako o jesieni życia — tak pisał już Cyceron - przez analogię do pór roku, następujących kolejno po sobie w życiu przyrody. Widzimy, jak w ciagu roku zmienia się otaczający nas świat, gdy patrzymy na góry i równiny, pola i doliny, lasy, rośliny i drzewa. Istnieje bliskie podobieństwo między rytmami biologicznymi człowieka a cyklami życia przyrody, której i on jest częścią" - takich odwołań użył w 1999 r. Ojciec Święty Jan Paweł II w Liście do moich braci i sióstr - ludzi w podeszłym wieku"4. Papież powołał się w nim na poglądy jednego z wielkich autorytetów starożytności, piszących o starości: Marka Tulliusza Cycerona, autora dzieła Cato Maior de senectute 5 . Ten słynny mówca napisał go w 44 r. prz.

\footnotetext{
${ }^{1}$ Por. E. Eyben, Old age in Graeco-Roman antiquity and early Christianity. An annotated select bibliography, w: Old age in Greek and Latin literature, ed. M. Falkner - J. De Luce, Albany (NY) 1989, 230-251. W. Suder, GERAS. Old age in Graeco-Roman antiquity. A classified bibliography, Wrocław 1991.

${ }^{2} \mathrm{Z}$ nowszych prac poświęconych starości w starożytnym Rzymie zob. H. Brandt, Wird auch silbern mein Haar. Eine Geschichte des Alters in der Antike, München 2002; tenże, Am Ende des Lebens. Alter, Tod und Suizid in der Antike, München 2010; M. Harlow - R. Laurence, Growing up and growing old in ancient Rome. A life course approach, London 2002; K. Cokayne, Experiencing old age in ancient Rome, London -New York 2003; T. Parkin, Old age in Roman world. A cultural and social history, Baltimore 2003; O. Fuà, Da Cicerone a Seneca, w: Senectus. La vecchiaia nel mondo classico, ed. U. Mattioli, vol. II: Roma, Bologna 1995, 182-238, spec. 182-210 (Cicerone).

${ }^{3}$ Por. Old age in Greek and Latin literature, dz. cyt.

${ }^{4}$ Joannes Paulus II, Nuntius christifidelibus provectioris aetatis missus (1 X 1999) 5, AAS 92 (2000) 192, lub Insegnamenti Giovanni Paolo II 22/2, 520, thum. List Ojca Świętego Jana Pawła II „Do braci i sióstr - ludzi w podeszłym wieku”. Stowa Ojca Świętego do ludzi starszych (1 X 1999) 5, Kraków 1999; lub tłum. Jan Paweł II, List do osób w podeszłym wieku, Poznań 1999.

${ }^{5}$ Por. tamże, przypis 9: Marci Tullii Ciceronis Cato Maior, seu de senectute 19, 70, ed.
} 
Chr. i zadedykował swemu przyjacielowi Attykowi. Sam autor miał wówczas prawie 62 lata (Attyk 65 lat), za sobą karierę polityczną, przerwaną dyktaturą Cezara oraz przeżyte nieszczęście w 45 r., którym była śmierć córki Tullii. Był to okres, w którym Cyceron poświęcał się pracy pisarskiej, głównie nad traktatami filozoficznymi ${ }^{6}$. Jednym $\mathrm{z}$ aspektów filozoficznych, związanych z życiem człowieka była starość. Jak podaje sam autor:

„Praca nad tą książeczką tak była miła, że pozwoliła mi zapomnieć o wszystkich przykrościach starszego wieku, co więcej starość wydała mi się lekką, a nawet wprost przyjemną"7.

Autor więc nie tylko chciał pocieszyć przyjaciela, ale również znaleźć usprawiedliwienie dla własnych problemów zbliżającej się starości ${ }^{8}$.

Cyceron zastosował $\mathrm{w}$ utworze swoją ulubioną formę dialogu, przenosząc jednak akcję przeszło sto lat wstecz'. Głównym uczestnikiem dialogu jest Marek Porcjusz Katon Starszy, prezentujący w tym przypadku poglądy samego Cycerona ${ }^{10}$. Jego partnerami są: Publiusz Korneliusz Scypion Młodszy - przyszły zwycięzca w III wojnie punickiej oraz Gajusz Leliusz Sapiens, konsul z 140 r. prz. Chrystusem. Akcja dialogu rozgrywa się w 150 r. prz. Chr., kiedy Katon Starszy miał 84 lata. Jego rozmówcy byli znacznie młodsi, stąd też w traktacie odgrywają głównie rolę słuchaczy ${ }^{11}$. Arpinata idealizuje niewątpliwie postać słynnego cenzora, znanego z surowości, tu zaś ukazanego jako sympatycznego starca, o dobrej kondycji fizycznej i dużej wiedzy, wygłaszającego łagodnie, bez zacietrzewienia swoje poglądy ${ }^{12}$.

J.G.F. Powell, Cambridge 1988. Cytaty w thumaczeniu: Z. Cierniakowa: Cyceron, Katon Starszy o starości, w: Pochwała starości, wstęp i przypisy M. Szymański, Warszawa 1996, 64 (cytuję wg tego wydania), lub w: Cyceron, Pisma filozoficzne, IV, Warszawa 1963, 49; inne polskie przekłady traktatu: thum. E. Rykaczewski: Pisma filozoficzne M.T. Cycerona, VIII, cz. 2, Poznań 1879, 145-177; thum. W. Klimas: Marek Tuliusz Cyceron, Katon Starszy o starości, wstęp i oprac. S. Stabryła, Kraków 1995.

${ }^{6}$ Por. A. Everitt, Cicero. A turbulent life, London 2001, 241-242.

${ }^{7}$ Cicero, De senectute 1, 2: „Mihi quidem ita iucunda huius libri confecto fuit, ut non modo omnis absterserit senectutis molestias, sed effecerit mollem etiam et iucundam senectutem", thum. Cierniakowa, s. 28. Aspekty filozoficzne traktatu Cycerona podkreśla T. Ożóg: M.T. Cycerona apologia starości, w: Dorostość wobec starości. Oczekiwania - radości-dylematy, red. R. KoniecznaWoźniak, Poznań 2008, 165-174.

${ }^{8}$ Por. A. Trojnar, Marka Tulliusza Cycerona traktat „, O starości”, w: Starość. Wybór materiałów z VII Konferencji Pracowników Naukowych i Studentów Instytutu Nauk o Literaturze Polskiej UŚ, red. A. Nawarecki - A. Dziadek, Katowice 1995, 54-60.

${ }^{9} \mathrm{Na}$ temat kompozycji utworu por. Powell, Introduction, s. 1-2.

${ }^{10}$ Por. Cicero, De senectute 1, 3.

${ }^{11} \mathrm{O}$ relacjach między Katonem, Scypionem i Leliuszem por. A. Astin, Scipio Aemilianus and Cato Censorius, „Latomus” 15 (1956) 159-180; S. Szczygieł, Marek Porcjusz Katon - rzymski tradycjonalista czy polityk realista, Warszawa 2011, 85.

${ }^{12}$ Por. Szymański, Wstęp, w: Pochwała starości, s. 13; Szczygieł, Marek Porcjusz Katon, s. 14. 
Przy pisaniu tego dialogu Cyceron wzorował się na greckim traktacie o starości perypatetyka z III wieku prz. Chr. Arystona z Keos, którego bohaterem jest mityczny Titonos ${ }^{13}$. Są także hipotezy, że Arpinata mógł w tym wypadku korzystać z jakiegoś pisma o starości Teofrasta lub innego nieznanego nam autora ${ }^{14}$. Koncepcja realizacji traktatu opiera się na zestawieniu dwóch różnych poglądów na starość: $\mathrm{z}$ jednego z nich przebija smutek i niepokój, którego podsumowaniem są słowa Scypiona:

„A przecież starzy ludzie tak jej nienawidzą! Twierdzą że odczuwają ją jak ogromny ciężar, większy od Etny"15.

W dodatku dla ludzi starszych przychodzi ona zbyt szybko. Sam autor wspomina o ciężarze i niedogodnościach starości, które postanowił zwalczyć przy pomocy filozofii ${ }^{16}$. Drugi pogląd, reprezentowany przez Katona, obala zarzuty przeciw starości, zalecając spokój, aktywność i umiarkowanie ${ }^{17}$. Cyceron uznaje starość za rzecz naturalną. Jak wspomniano wyżej, porównuje życie do pór roku, w których po wiośnie życia, następuje lato i jesien ${ }^{18}$. Jednocześnie krytykuje ludzi, którzy pragną dożyć starości, lecz gdy nadejdzie, narzekają na nią ${ }^{19}$.

Cyceron słowami Katona wylicza cztery przyczyny, które sprawiają, że ludzie uważają starość za nieszczę́liwy okres życia: a). oddala nas od życia czynnego, b). osłabia siły fizyczne, c). pozbawia nas wszystkich zmysłowych przyjemności, d). bliska jest śmierci ${ }^{20}$. Przytoczone zarzuty przeciwko starości powodowały, że ludzie niechętnie odnosili się do tego okresu życia. Katon zatem w dialogu stara się przeprowadzić analizę wymienionych powodów, dokumentując wręcz przeciwne spojrzenie na problem starości. Charakterystyczne jest

${ }^{13}$ Por. Cicero, De senectute 1, 3, thum. Cierniakowa, s. 28: „Nie występuje w niej jednak Tyton, jak to widzimy u Arystona z Chios, nie chciałem bowiem postacią z bajki osłabiać wartości swoich wywodów". Za tym autorem, a przeciwko stoikowi Arystonowi z Chios, opowiada się: L. Alfonsi, Sulle fonti del „De senectute”, „La Parola del Passato” 41 (1955) 121-129; zob. też Powell, Commentary, s. 269. O Titonosie zob. H. King, Tithonos and the Tettix, w: Old age in Greek and Latin literature, s. 68-89.

${ }^{14} \mathrm{O}$ innych przypuszczalnych źródłach traktatu Cycerona zob. K. Kumaniecki, Literatura rzymska. Okres cyceroński, Warszawa 1977, 363; Powell, Introduction, s. 24-25.

${ }^{15}$ Cicero, De senectute 2, 4. ,senectutem [...], quae plerisque senibus sic odiosa est, ut onus se Aetna gravius dicant sustinere", tłum. Cierniakowa, s. 29.

${ }^{16}$ Por. tamże 1, 2, Cierniakowa, s. 27: „Postanowiłem napisać cośkolwiek o innym, również wspólnym nam ciężarze: o bliskiej, a może już nękającej nas starości”.

${ }_{17}$ Por. E. Narducci, Il „Cato Maior” o la vecchiezza dell'aristocrazia romana, „Quaderni di Storia" 8 (1982) 121-163.

${ }^{18}$ Por. Cicero, De senectute 19, 70.

${ }^{19}$ Por. tamże 2, 4.

${ }^{20}$ Por. tamże 5, 15: „Etenim, cum complector animo, quattuor reperio causas, cur senectus misera videatur: unam, quod avocet a rebus gerendis; alteram, quod corpus faciat infirmius; tertiam, quod privet fere omnibus voluptatibus; quartam, quod haud procul absit a morte", thum. Cierniakowa, s. 35. 
przy tym, że Cyceron obok argumentacji filozoficznej czy medycznej, przywołuje także aspekty polityczne, religijne, społeczne i kulturowe ${ }^{21}$.

Z pierwszym zarzutem Katon rozprawia się bez trudu, wyliczając słynnych w przeszłości Rzymian: wodzów i polityków (m.in. Kwintusa Fabiusza Maksymusa, Scypiona Afrykańskiego Starszego, Lucjusza Paulusa, Appiusza Klaudiusza) prowadzących aktywne życie polityczne pomimo podeszłego wieku. Wyjaśnia, że starzec nie robi tego, co ludzie młodzi, robi za to rzeczy ważniejsze i lepsze. Jest niczym siedzący nieruchomo sternik, kierujący okrętem, otoczony przez gromadę bezładnie biegających we wszystkich kierunkach marynarzy 22 .

Najważniejszym problemem ludzi starych był udział w życiu publicznym. Wiązało się to z pewnymi ograniczeniami dotyczącymi sprawowania funkcji publicznych oraz udziału w senacie i zgromadzeniach. Lex Acilia de repetundis z 123 r. prz. Chr. zwalniała osoby powyżej sześćdziesiątego roku życia $\mathrm{z}$ zasiadania $\mathrm{w}$ senacie ${ }^{23}$. Zaprzeczał temu sam Cyceron, który twierdził, że starzy ludzie mogą służyć ojczyźnie rozwagą, rozumem, mądrym słowem:

„Gdyby te zalety nie były cechą starości, przodkowie nasi nie nazwaliby byli najwyższej rady senatem od słowa senex (starzec)"'24.

Także liczne przykłady z okresu późnej republiki wskazują, że był to raczej przywilej ludzi starszych niż obowiązek ${ }^{25}$.

Z kolei u niektórych autorów rzymskich pojawia się sformułowanie: sexagenarios de ponte deici oportere. Cyceron w swej mowie: W obronie Rocjusza $z$ Amerii wspomina:

„Habeo etiam dicere, quem contra morem maiorum minorem annis sexaginta de ponte in Tiberim deiecerit" 26 .

Wynikałoby stąd, że ludzi starszych zrzucano z mostu do Tybru ${ }^{27}$. Większość współczesnych badaczy odrzuca jednak tę sugestię przyjmując, że chodziło o uczestnictwo w zgromadzeniach centurialnych, które odbywały się na Polu Marsowym i w trakcie których głosujący przechodzili z tabliczkami przez specjalne mostki. Były to zgromadzenia o charakterze wojskowym, stąd też

${ }^{21}$ Por. L. Alfonsi, Das ciceronische Denken in „De Senectute”, w: Das neue Cicerobild, hrsg. K. Büchner, Darmstadt 1971, 208-228.

${ }^{22}$ Por. Cicero, De senectute 6, 16 - 8, 26.

${ }^{23}$ Por. W. Suder, ,, Sexagenarios de ponte”. Ludzie starzy w rodzinie i spoleczeństwie rzymskim $w$ świetle prawa, w: Starożytny Rzym we współczesnych badaniach, red. J. Wolski - T. Kotula A. Kunisz, Kraków 1994, 319-327.

${ }^{24}$ Cicero, De senectute 6, 19, thum. Cierniakowa, s. 37.

${ }^{25}$ Por. F.X. Ryan, Rank and participation in the Republican Senate, Stuttgart 1998, 137-138.

${ }^{26}$ Cicero, Pro Sexto Roscio Amerino 35, 100.

${ }^{27}$ Por. Ovidius, Fasti V 633-634: ,pars putat, ut ferrent iuvenes suffragia soli, pontibus infirmos praecipitasse senes. Thybri doce verum", Owidiusz jednak powatpiewa w te relacje. 
odmawiano sześćdziesięciolatkom w nich udziału ${ }^{28}$. Wspomina o tym Festus przytaczając słowa Sinniusza Kapito:

„Sed exploratissimum illud est causae, quo tempore primum per pontem coeperunt comitiis suffragium ferre, iuniores conclamaverunt, ut de ponte deicerentur sexagenari, qui iam nullo publico munere fungerentur, ut ipsi potius sibi quam illi deligerent imperatorem: cuius sententiae est etam Sinnius Capito"29.

Inaczej jednak sądzi F.X. Ryan, który sugeruje, że mogło chodzić o centuria praerogativa, która głosowała jako pierwsza, a którą wylosowywano spośród iuniores $^{30}$. Festus wspomina też o zakazie pełnienia obowiązków publicznych (munera publica). Prawdopodobnie, jak w przypadku uczestnictwa w senacie, był to raczej przywilej osób starszych ${ }^{31}$.

Innym argumentem przemawiającym przeciwko ograniczeniom aktywności ludzi starszych są ich działania w sferze intelektualnej i kulturalnej. Cyceron wylicza wybitnych pisarzy i filozofów, zarówno greckich, jak też rzymskich, którzy pod koniec swego życia nadal tworzyli, a powstałe wówczas utwory często okazywały się lepsze niż poprzednie ${ }^{32}$. Jedynym ich problemem może być pamięć, która słabnie z wiekiem. Autor stwierdza:

„Owszem - lecz tylko wtedy, gdy jej nie ćwiczymy lub jeśli z natury mamy umysł mniej żywy"33.

Poważniejszą przeszkodą w aktywności ludzi starszych, wymienioną w traktacie jako drugi zarzut przeciwko starości, jest osłabienie organizmu, prowadzące niekiedy do chorób i niedołęstwa. Katon w dialogu krytykuje tego typu podejście do starości stwierdzając, że człowiekowi starszemu nie jest już potrzebna wielka siła fizyczna:

„A choćby nawet starość sił fizycznych nie miała - to przecież nikt od niej ich nie wymaga. Zarówno prawa, jak i zwyczaje zwalniają nasz wiek od tych zajęć, przy których siły fizyczne nie są konieczne. Nie żąda się więc od nas nawet tego, czemu podołać możemy - a cóż dopiero tego co nasze siły przerasta"34.

\footnotetext{
${ }^{28}$ Por. J.P. Néraudau, ,, Sexagenarii de ponte”. Réflections sur la genèse d'un proverbe, REL 56 (1978) 159-174; Suder, ,, Sexagenarios de ponte”, s. 325-326.

${ }^{29}$ Sextus Pompeius Festus, De verborum significatione, ed. W. Lindsay, Leipzig 1913, 452; por. Warro u Nonniusa Marcellusa, tamże, s. 842.

${ }^{30}$ Por. F.X. Ryan, Sexagenarians, the bridge, and the,, centuria praerogativa”, ,Rheinisches Museum für Philologie" 138 (1995) 188-190.

${ }^{31}$ Szerzej na temat uczestnictwa osób starszych w życiu publicznym zob. P. Soverini, Senectus e res publica: la storiografia romana, w: Senectus. La vecchiaia nel mondo classico, ed. U. Mattioli, vol. II: Roma, Bologna 1995, 240-258.

32 Por. Cicero, De senectute 7, 22-23.

33 Tamże 7, 21: „At memoria minuitur. Credo, nisi eam exerceas, aut etiam si sis natura tardior”.

34 Tamże 11, 34: „Non sunt in senectute vires. Ne postulantur quidem vires a senectute. Ergo et
} 
Sposobem zaś na zachowanie w miarę sił fizycznych i krzepkości na starość są ćwiczenia i panowanie nad sobą ${ }^{35}$. Z kolei niedołęstwo starców jest skutkiem nie starości, ale ogólnie słabego zdrowia ${ }^{36}$. Podaje przy tym zalecenia dla osób starszych:

„nie dać się starości i jej wady skrzętnie wyrównywać, walczyć z nią jak walczy się z chorobą; trzeba też mieć wzgląd na zdrowie: używać w miarę ćwiczeń, jeść i pić tylko tyle, by wzmocnić siły, a nie osłabiać ich nadmiarem jedzenia" ${ }^{\text {"37 }}$.

Kontrastem, ale też uzupełnieniem dla dbałości o stan fizyczny i ciało, są działania w sferze umysłowej i duchowej ${ }^{38}$. Starość nie musi wiązać się z osłabieniem zdolności intelektualnych. Katon stwierdza:

„Człowiek stary może zachować nienaruszone władze umysłowe, byle nie zaprzestał nad nimi pracować" 39 .

Jednocześnie przywołuje własny przykład pracy nad podtrzymaniem intelektu: zbieranie materiałów do VII księgi Origines, odtwarzanie mów obrończych, praca nad prawem auguralnym, pontyfikalnym i cywilnym. Wieczorem, dla ćwiczenia pamięci powtarzanie tego co w danym dniu mówił, słyszał i robił ${ }^{40}$. Dzięki zaletom ludzi starszych: rozwadze, powadze decyzji, dojrzałości i doświadczeniu mogą oni dokonywać wielkich rzeczy. Dotyczy to oczywiście tylko ludzi, którzy starają się wzmacniać umysł przez stosowne ćwiczenia ${ }^{41}$. Ich przeciwstawieniem są osoby starsze nie pracujące nad sobą których określa za Cecyliuszem ,głupimi starcami z komedii”, a ich cechy to: łatwowierność, otępiałość, gnuśność i brak energii ${ }^{42}$.

legibus et institutis vacat aetas nostra muneribus eis, quae non possunt sine viribus sustineri. Itaque non modo, quod non possumus, sed ne quantum possumus quidem cogimur", thum. Cierniakowa, s. 45.

${ }^{35}$ Por. Cokayne, Experiencing old age, s. 9-10 (rozdział: Physical aspects of old age).

${ }^{36}$ Por. Cicero, De senectute 11, 35: „At multi ita sunt imbecilli senes, ut nullum offici aut omnino vitae munus exsequi possint. At id quidem non proprium senectutis vitium est, sed commune valetudinis", por. thum. CIerniakowa, s. 45.

${ }^{37}$ Tamże 11, 35-36: „Resistendum, [...] senectuti est, eiusque vitia diligentia compensanda sunt, pugnandum tamquam contra morbum sic contra senectutem; habenda ratio valetudinis, utendum exercitationibus modicis, tantum cibi et potionis adhibendum ut reficiantur vires, non opprimantur”, thum. Cierniakowa, s. 45; por. E. Hübner, Ciceros „De senectute” in gerontologischer Schau, „Das Altertum” 3 (1957) 46-52.

${ }^{38}$ Por. Cicero, De senectute 10, 33, thum. Cierniakowa, s. 44, gdzie Katon zadaje pytanie: „Czy wolelibyście mieć siłę mięśni Milona, czy też siłę umysłu Pitagorasa.

${ }_{39}$ Tamże 7, 22: „Manent ingenia senibus, modo permaneat studium et industria”, thum. Cierniakowa, s. 38.

40 Por. tamże 11, 38; zachowane tylko fragmentarycznie dzieło Origines, nad którym Katon pracował w latach 168-149 przedstawiało dzieje Rzymu od Eneasza aż do czasów jemu współczesnych. Ostatnia jego księga VII wspomina nawet o wydarzeniach późniejszych niż akcja naszego dialogu, zob. też Szczygieł, Marek Porcjusz Katon, s. 185-186.

${ }^{41}$ Por. Cokayne, Experiencing old age, s. 57nn ( rozdział: Intellectuall aspects of old age).

${ }^{42}$ Cicero, De senectute 11, 36, thum. Cierniakowa, s. 46; por. Cokayne, Experiencing old age, s. 59-60. 
Trzecim zarzutem wobec starości było: pozbawienie człowieka starego wszystkich zmysłowych przyjemności. Katon krytykuje te osoby starsze, które narzekają, że starość pozbawiła ich przyjemności i rozkoszy, bez których życie nie jest życiem ${ }^{43}$. Uznaje to bowiem nie za przeszkodę, ale wspaniały dar, który pozwala uniknąć występków młodości. Przytacza przy tym poglądy Archytasa z Tarentu, który twierdził, że natura nie dała człowiekowi nic bardziej niebezpiecznego i zgubnego nad zmysłowość, której chciwe żądze w sposób bezmyślny i niepowściągliwy szukają zaspokojenia:

„Dla nich to zdradza się ojczyznę, dokonuje przewrotów politycznych, tajemnie knowa z wrogiem, nie ma w ogóle żadnej zbrodni, żadnego przestępstwa, do których popełnienia nie pobudziłaby żądza rozkoszy: gwałty, cudzołóstwa i wszelkie tego rodzaju czyny haniebne wywołane są jej ponętami”"44.

Cyceron nawiązał w tym przypadku zarówno do poglądów osobistych Katona, jak również do jego działalności w okresie cenzury w 184 r. prz. Chr., w trakcie której zasłynął ze swej surowości w obronie obyczajów, wykreślając za nie z listy senatorów m.in. 7 osób, w tym byłego konsula Lucjusza Kwinkcjusza Flamininusa $^{45}$. Odnosi się to również do problemów z ograniczeniem popędu seksualnego. Autor twierdzi, że starcy wcale tego nie pragną, zwłaszcza ci, którzy wcześniej zdążyli zaspokoić swoje pożądania. Proponuje im w zamian inną formę przyjemności, podobną do roli widza w teatrze:

„Starość, patrząc na rozkosze z oddalenia, potrafi się nimi cieszyć na tyle, na ile jest to jej potrzebne" ${ }^{" 46}$.

Sam Katon zaprzecza, że występuje przeciwko wszelkim przyjemnościom fizycznym, domaga się jedynie ich ograniczenia i dostosowania do wieku. Przykładem mogą być uczty. Zarzucano mu, że ludzie starsi nie mogą, według niego, brać udziału w hucznych biesiadach, „muszą powstrzymywać się od suto zastawionych stołów i często nalewanych kielichów" ${ }^{47}$. Według Katona ludzie starsi mogą uczestniczyć w przyjęciach, stosując jednak umiar w jedzeniu i piciu:

${ }^{43}$ Por. Cicero, De senectute 3, 7.

${ }^{44}$ Tamże 12, 40: „Hinc patriae proditiones, hinc rerum publicarum eversiones, hinc cum hostibus clandestina colloquia nasci; nullum denique scelus, nullum malum facinus esse, ad quod suscipiendum non libido voluptatis impelleret; stupra vero et adulteria et omne tale flagitium nullis excitari aliis inlecebris nisi voluptatis", thum. Cierniakowa, s. 48; Archytas z Tarentu (IV w. prz. Chr.) - matematyk i filozof pitagorejski.

${ }^{45}$ Por. tamże 12, 42; zob. Livius, Ab Urbe condita XXXIX 42, 5-12 i 43, 1-4; Plutarchus, Cato Maior 17; Valerius Maximus, Factorum et dictorum memorabilium II 9; Ps. Sextus Aurelius Victor, De viris illustribus 47, 4. Szerzej na temat działalności Katona w okresie cenzury zob. Szczygieł, Marek Porcjusz Katon, s. 81-82.

${ }^{46}$ Cicero, De senectute 14, 47-48, thum. Cierniakowa, s. 52-53; por. Cokayne, Experiencing old age, s. 115-116.

${ }^{47}$ Cicero, De senectute 13, 44, thum. Cierniakowa, s. 50. 
„[...] lubię, kiedy każdy począwszy od szczytu stołu, przemawia nad czarą z winem. Ale lubię też popijać powoli, kropla po kropli, z maleńkich kubków [...]. Miły mi również jest chłód w lecie, a ciepło słońca i ogniska w zimie"48.

Zaletą jest brak negatywnych skutków pijaństwa i obżarstwa, natomiast pozytywnym elementem uczt, nawet trwających dość długo jest możliwość prowadzenia rozmów z przyjaciółmi.

Krytykuje przy tym negatywne zjawiska, które pojawiają się w u niektórych ludzi w starszym wieku: zdziwaczenie, zgryźliwość, podejrzliwość, drażliwość i upór. Uznaje je jednak za indywidualne wady charakteru nie związane z wiekiem: „Ludzie są jak wino: nie wszyscy na starość kwaśnieją"49. Szczególnie dziwi go skąpstwo i gromadzenie dóbr na starość, które porównuje do wielkich zapasów na drogę, której niewiele zostało już do przeby$\mathrm{cia}^{50}$. Przeciwstawieniem ich jest rozum i kontrola nad zmysłami, które cechują ludzi starszych. Przyjemnością ludzi starszych może być realizacja ich zainteresowań, zwłaszcza zamiłowań intelektualnych, do literatury, filozofii czy prawa ${ }^{51}$. Inną zaletą starości jest zdobywanie szacunku i poważania. Nie jest to jednak przynależne starcom z natury, gdyż powagę zdobywa się już od młodości poprzez swoje działania ${ }^{52}$.

Największą zaletą starości jest, zdaniem Cycerona, szacunek oraz możliwość udzielania rad młodzieży, zwłaszcza własnym dzieciom. Wiązało się to z rzymską pietas, która regulowała przede wszystkim relacje między poszczególnymi członkami rodziny, np. dzieci wobec rodziców (pietas erga parentes) czy rodziców wobec dzieci (pietas erga liberos). Cyceron definiował ją następująco:

„Pietatem, quae erga patriam, aut parentes, aut alios sanguine coniunctos officium conservare monet" ${ }^{\prime \prime 3}$.

Do wymienionych obowiązków należały: posłuszeństwo, przestrzeganie nakazów oraz cześć i szacunek w obrębie rodzin. Rodzicom przysługiwała nie tylko cześć, lecz również miłość, wierność i wdzięczność ze strony dzieci. W mowie $W$ obronie Plancjusza Cyceron stwierdza: „Quid est pietas, nisi voluntas

${ }^{48}$ Tamże 14, 46: „Me vero et magisteria delectant a maioribus instituta et is sermo, qui more maiorum a summo adhibetur in poculo, et pocula, sicut in Symposio Xenophontis est, minuta atque rorantia, et refrigeratio aestate et vicissim aut sol aut ignis hibernus", tłum. Cierniakowa, s. 52.

${ }^{49}$ Tamże 18, 65, tłum. Cierniakowa, s. 62.

${ }^{50}$ Por. tamże 18, 66.

${ }^{51}$ Por. tamże 14, 49-50.

${ }^{52}$ Por. tamże 18, 62, thum. Cierniakowa, s. 61: ,[...] ani siwe włosy, ani zmarszczki nie są w stanie nagle zdobyć dla siebie poważania"; zob. Brand, Wird auch silbern mein Haar, s. 127-128.

${ }^{53}$ Cicero, De inventione II 66; tamże II 161: „pietas, per quam sanguine coniuctis patriaeque benevolum officium et diligens tribuitur cultus". 
gratia in parentes?" ${ }^{54}$. Sam mówca obowiązek oddawania czci ojcu uznał za jeden z fundamentów rodziny i społeczeństwa ${ }^{55}$.

Inną przyjemnością, dostępną nie tylko dla ludzi starszych, są uroki życia wiejskiego. Katon, jako autor dzieła $O$ gospodarstwie wiejskim, zachęca ludzi starszych do osiedlania się na wsi. Zaletą tego jest możliwość własnoręcznej pielęgnacji winnej latorośli, drzew oliwnych i owocowych, warzyw i innych roślin ogrodowych. Można też obserwować rozwój roślin, poczynając od ziarenek aż do rozwoju owoców, podziwiać piękno przyrody, uczestniczyć w polowaniach i łowieniu ptaków. Pozytywnym elementem życia wiejskiego jest również możliwość korzystania z obfitości wytwarzanych tam dóbr: warzyw, mleka, sera, mięsa, miodu ${ }^{56}$. Charakterystyczne jest przy tym, że wymieniony pogląd nie był tylko przypomnieniem koncepcji Katona, ale również odzwierciedleniem ówczesnej postawy Cycerona, który po powrocie Cezara usunął się na wieś, zajmując się rolnictwem i filozofią.

Największą trwogą starców jest przeświadczenie, że nieuchronnie zbliża się śmierć. Nie jest to jednak wyłączna obawa ludzi starszych: „śmierć nie oszczędza żadnego wieku"57. Katon krytykuje pogląd, że ludzie młodzi moga spodziewać się dłuższego życia, a starcy już nie. Przyszłość jest zawsze niewiadoma, starcy zaś są w lepszej sytuacji, gdyż już osiagnęli co chcieli, a młodzi dopiero tego pragną. Śmierć jest zjawiskiem naturalnym, gdy umieramy, musimy to w jakiś sposób odczuwać, trwa to jednak krótko, zwłaszcza u starców. Jednakże gdy umiera ktoś młody jest wrażenie: , jakby ktoś strumieniem wody zdusił nagle wielki płomień - starzec zaś gaśnie spokojnie, jak ognisko, które się samo z siebie dopala" ${ }^{58}$.Katon przywołuje przy tym postać własnego syna, którego wcześniej pochował ${ }^{59}$.

Argumentując konieczność wyzbycia się obawy przed śmiercią Cyceron sięga do filozoficznego arsenału rzymskiego stoicyzmu:

„Jest tylko jedno z dwojga: albo śmierć całkowicie gasi życie duszy albo prowadzi ją tam, gdzie żyć będzie wiecznie. W pierwszym przypadku jest ona czymś obojętnym, w drugim zaś jest nawet pożądania godna" ${ }^{\circ 0}$.

${ }^{54}$ Cicero, Pro Plancio 80.

${ }^{55}$ Por. R. Saller, Pietas. Obligation and authority in the Roman family, w: Alte Geschichte und Wissenschaftsgeschichte. Festschrift für Karl Christ zum 65. Geburtstag, hrsg. P. von Kneissl, Darmstadt 1988, 393-410; H. Kowalski, Pietas jako wyznacznik odniesień między rodzicami a dziećmi w republikańskim Rzymie, w: Dziecko w rodzinie i społeczeństwie, red. J. Jundziłł - D. ŻołądźStrzelczyk, t. 1, Bydgoszcz 2002, 86-96.

${ }^{56}$ Por. Cicero, De senectute 15, 51 - 17, 60.

${ }^{57}$ Tamże 19, 68: „mortem omni aetati esse communem”.

${ }^{58}$ Tamże, 19, 71, tłum. Cierniakowa, s. 63.

${ }^{59}$ Por. tamże 23, 84.

${ }^{60}$ Tamże 19, 66-67, thum. Cierniakowa, s. 63. 
Autor prezentuje tu funkcjonujące wówczas wśród arystokracji rzymskiej poglądy na temat śmierci ${ }^{61}$. Przedstawicielem pierwszego nurtu był Cezar, który podczas procesu Katylinarczyków w grudniu 63 r. prz. Chr. stwierdził:

„[...] muszę powiedzieć zgodnie z tym, co jest w istocie, że w bólu i w nieszczęściach śmierć jest wypoczynkiem, a nie męką; poza nią nie ma już miejsca ani na troskę, ani na radość"

Tradycyjne poglądy na temat świata pozagrobowego prezentował podczas tego procesu Katon Młodszy:

„Pięknie i składnie rozprawiał przed chwilą w tym gronie Gajusz Cezar o życiu i śmierci, uważając jak sądzę, za bajki to, co się opowiada o życiu pozagrobowym, mianowicie, że tam ludzie źli oddzieleni są od dobrych, zamieszkują okolice wstrętne, puste, ohydne i grozę budzące"63.

Sam Cyceron podczas procesu krytycznie ustosunkował się do poglądów Cezara ${ }^{64}$. Po kilkunastu latach Cyceron podjął na ten temat rozważania filozoficzne i problematyce śmierci poświęcił I księgę swej rozprawy Tusculanae disputationes ${ }^{65}$. Przeprowadził w niej krytykę tradycyjnych poglądów dotyczących świata pozagrobowego:

„[...] tego zaś, gdzie dusze przebywają i jakie mają własności musimy dociekać za pomocą rozumu. Niewiedza w tej dziedzinie stworzyła świat podziemny i te okropności, dla których myślę, że nie bez słuszności miałeś pogardę"

Sam opowiadał się za platońską koncepcją nieśmiertelności duszy, której stał się zwolennikiem ${ }^{67}$, do niej odwołał się również w De senectute, gdzie Katon nawołuje:

${ }^{61}$ Por. A. Momigliano, The theological efforts of the Roman upper classes in the first century B.C., CPh 79 (1984) 199-211.

${ }^{62}$ Sallustius, De coniuratione Catilinae 51; „De poena possum equidem dicere, id quod res habet, in luctu atque miseriis mortem aerumnarum requiem, non cruciatum esse; eam cuncta mortalium mala dissolvere; ultra neque curae neque gaudio locum esse", thum. K. Kumaniecki: Gajus Salustiusz Krispus, Sprzysiężenie Katyliny i wojna z Jugurta, Wrocław - Warszawa - Kraków 1971, 27.

${ }^{63}$ Tamże 52: „Bene et conposite C. Caesar paulo ante in hoc ordine de vita et morte disseruit, credo falsa existumans ea, quae de inferis memorantur: divorso itinere malos a bonis loca taetra, inculta, foeda atque formidulosa habere", thum. Kumaniecki, s. 30.

${ }^{64}$ Por. Cicero, In Catilinam IV, 7-8.

${ }^{65}$ Por. Cicero, Tusculanae disputationes I, passim.

${ }^{66}$ Tamże I 16, 36: „sic permanere animos arbitramur consensu nationum omnium, qua in sede maneant qualesque sint, ratione discendum est. cuius ignoratio finxit inferos easque formidines, quas tu contemnere non sine causa videbare", tłum. J. Śmigaj, w: Marcus Tullius Cicero, Pisma filozoficzne, III, Biblioteka Klasyków Filozofii 57, Warszawa 1961, 502.

${ }^{67}$ Cicero, Somnium Scipionis, w: tenże, De republica VI 13, thum. W. Kornatowski, w: Marcus Tullius Cicero, Pisma filozoficzne, II, Warszawa 1960, 177: „Dla wszystkich, którzy ochraniali, wspierali i umacniali ojczyznę, jest wyznaczone w niebie określone miejsce, gdzie będą doznawać wiecznej szczęśliwości”; por. M. Jaczynowska, Religie świata rzymskiego, Warszawa 1987, 95-96. 
„Wierzcie wiec, że ona nie przestanie istnieć i działać, choć jej również nie będziecie widziećc8

Twierdzi też, ze po śmierci dusza osiaga postać boską. Potwierdzają to słowa Cycerona, który w traktacie De legibus wspomina, że przodkowie chcieli:

„by osoby, które rozstały się z tym życiem, zaliczane były pomiędzy bogów" (nisi maiores eos qui ex hac vita migrassent in deorum numero esse voluissent $)^{69}$.

Autor ten wspomina także, że dusze zmarłych utożsamiane są z Di Manes ${ }^{70}$. Wiązało się to z wyobrażeniami świata podziemnego, w którym ważną rolę opiekuńczą nad duszą zmarłego przejmowały wspomniane bóstwa Di Manes ${ }^{71}$. Wiara ta pozwalała wyzbyć się obawy przed śmiercią. Katon mówi:

„Jakże szczęśliwy będzie dzień, w którym opuściwszy tę bezładną zbieraninę ludzką podążę tam, gdzie przebywają i gromadzą się boskie duchy. Spotkam tam bowiem nie tylko mężów, o których mówiłem, ale i mego Katona, najlepszego z synów, najszlachetniejszego spośród ludzi, jacy kiedykolwiek się urodzili" $" 72$.

Odrzuca jednocześnie myśl o powrocie do dzieciństwa:

„Gdyby zaś jakiś bóg chciał mi tę łaskę wyświadczyć, bym zaczął być na nowo dzieckiem i kwilił w kołysce, stanowczo nie zgodziłbym się na to. Nie chcę, dobiegłszy prawie do mety, wracać do startu"73.

$* * *$

Analizując przedstawione rozważania Cycerona na temat starości należy zauważyć, że Autor świadomie wystąpił w obronie wieku starszego: jego argumentacje są wielką pochwałą życia ludzi w starszym wieku. Cyceron przywołuje argumenty filozoficzne, odwołuje się też do kwestii fizjologicznych, psychologicznych, religijnych i politycznych. Zwalcza jednocześnie dość powszechne w społeczeństwie rzymskim wyobrażenia o ludziach starszych, podkreślające fizyczne, psychiczne, charakterologiczne i intelektualne wady i ograniczenia. Przedstawia je jako zarzuty wobec starości, podejmując jedno-

${ }^{68}$ Cicero, De senectute 22, 80, thum. Cierniakowa, s. 69.

${ }^{69}$ Cicero, De legibus II 55, tłum. W. Kornatowski, w: Marcus Tullius Cicero, Pisma filozoficzne, II, Warszawa 1960, 273; por. E.M. Štaerman, Socjalnyje osnovy religii drevnego Rima, Moskva $1987,50$.

${ }^{70}$ Por. Cicero, De legibus II 62; zob. J.M.C. Toynbee, Death and burial in the Roman world, Baltimore 1996, 32-33.

${ }^{71}$ Por. J.P. Jacobsen, Les Manes, t. 1: Les morts et la vie humaine, Paris 1924, 28-52; F. Bömer, Ahnenkult und Ahnenglaube im alten Rom, Leipzig - Berlin 1943, 17-20.

${ }^{72}$ Cicero, De senectute 23, 84, thum. Cierniakowa, s. 71-72.

73 Tamże 23, 83, thum. Cierniakowa, s. 71. 
cześnie słowami swego bohatera Katona polemikę, wyjaśnienia i gloryfikację zalet wieku starszego ${ }^{74}$. Teorie filozoficzne nie zawsze jednak znajdowały odzwierciedlenie w praktyce. Główny bohater jego traktatu Katon Starszy utrzymywał intymne stosunki z młodą niewolnica, a kiedy jego syn wykrył ten związek, postanowił ożenić się z córką swego klienta Saloniusa i w wieku 80 lat został ojcem M. Porcjusza Salonaniusa ${ }^{75}$.

Podobnie postapił sam Cyceron, który w 46 r. prz. Chr. rozwiódł się z 52-letnią żoną Terencją, żeniąc się z piętnastoletnią Publilią. Plutarch zauważa, że zrobił to głównie dla jej pieniędzy, chcąc się w ten sposób pozbyć licznych długów ${ }^{76}$. Małżeństwo to nie trwało jednak długo, bo już w 45 r. prz. Chr., po śmierci córki, Cyceron rozwiódł się z nową żoną ${ }^{77}$. Pisząc traktat De senectute, Cyceron miał więc za sobą już dwa małżeństwa, w tym jedno z młodą osobą. Jego filozoficzne poglądy na temat ograniczeń starości nie przystawały więc do praktycznych działań własnych i jego głównego bohatera. Plutarch pisze, że wykorzystał to przeciwnik Cycerona Marek Antoniusz, który w swych replikach na mowy Cycerona Filipiki zarzucał mu, że wyrzucił $\mathrm{z}$ domu kobietę, przy której się zestarzał ${ }^{78}$.

Apologia starości przekazana przez Cycerona, jest wyidealizowanym, filozoficznym przedstawieniem problemu; nie zawsze jednak znajdowała ona odzwierciedlenie w rzeczywistości. W źródłach rzymskich, zwłaszcza prawniczych, pojawiają się informacje o podejmowanych próbach samobójstwa czy eutanazji ludzi starszych. Podstawową tego przyczyną był stan zdrowia i ból fizyczny, a także choroby psychiczne ${ }^{79}$. Bezpośrednim motywem związanym ze starością było: taedium vitae - znużenie życiem. Oczywiście, starość nie była jedynym powodem zniechęcenia do życia, mogły dochodzić do tego także inne przyczyny: ból, choroba, nieszczęścia, utrata bliskiej osoby, motywy polityczne ${ }^{80}$. Taedium vitae doświadczył też sam autor traktatu De senectue Marek Tulliusz Cyceron. Jak podaje Liwiusz, w przekazanym przez Senekę Starszego fragmencie, Cyceron po zawiązaniu drugiego triumwiratu podjął

${ }^{74}$ Por. Ożóg, M.T. Cycerona apologia starości, s 166-167.

${ }^{75}$ Por. Plutarchus, Cato Minor 24; zob. Szczygieł, Marek Porcjusz Katon, s. 25-26.

${ }^{76}$ Por. Plutarchus, Cicero 41; zob. S. Treggiari, Terentia, Tullia and Publillia. The woman of Cicero 's family, London - New York 2007, 129-130.

${ }^{77}$ Por. Treggiari, Terentia, Tullia and Publillia, s. 140-141.

${ }^{78}$ Por. Plutarchus, Cicero 41.

${ }^{79}$ Por. M. in. Paulus, Digesta 487, 19, 38, 12: ,impatientia doloris, morbi causa”; 49, 14, 45, 2 : „valetudinis alicuius impatientia”; Ulpianus, Digesta 28, 3, 6, 7: „valetudinis adversae impatientia”; Arrius, Digesta 49, 16, 6, 7: „imatientia doloris, morbo, furore”; zob. Y. Grisé, Le suicide dans la Rome antique, Montreal - Paris 1982, 260-261.

${ }^{80}$ Szerzej M. Kuryłowicz, Taedium vitae w rzymskim prawie karnym, w: Contra leges et bonos mores. Przestęstwa obyczajowe w starożytnej Grecji i Rzymie, red. H. Kowalski - M. Kuryłowicz, Lublin 2005, 189-199; Brandt, Am Ende des Lebens, s. 87 nn (rozdział VI: Senectus, taedium vitae und mors volutaria). 
próbę ucieczki, jednakże niepowodzenia spowodowały, że: „taedium tandem eum et fugae et vitae cepit" przyjmując z rezygnacją śmierć ${ }^{81}$.

\section{PEACE OR SORROW? THE CONCEPTION OF OLD AGE AS DISCUSSED IN THE WRITINGS OF MARCUS TULLIUS CICERO}

\section{(Summary)}

One of the great authorities in the antiquity who wrote about old age was Marcus Tullius Cicero, the author of „Cato Maior De senectute [Cato the Elder on Old Age]”. The famous orator wrote this work in $44 \mathrm{BCE}$ and dedicated it to his friend Atticus. The author himself was almost 62 years old at that time, and Atticus 65. Cicero wrote the work in a dialogue form, setting the action in $150 \mathrm{BCE}$, the speakers being Marcus Porcius Cato the Elder, who in this case presented the views of Cicero, Publius Cornelius Scipio the Younger and Gaius Laelius Sapiens. Cicero followed the example of a Greek treatise on old age, probably written by a third-century BCE Peripatetic philosopher, Aristo of Ceos.

The concept of the presentation of the treatise is based on comparison of two different views on old age. In one, sorrow and anxiety are visible. Through Cato's words, Cicero names four reasons why people regard old age as an unhappy period of life: a). it moves us away from active life; b). it weakens physical strength, c). it deprives us of all sensual pleasures, d). it is close to death. The other view, represented by Cato, disproves the objections against old age, recommending calmness, activity, and moderation. Interestingly enough, apart from philosophical or medical arguments, Cicero also refers to political, religious, social and cultural aspects.

The apologia for old age presented by Cicero was not always reflected in the reality. Roman sources, especially legal documents, inform about attempted suicide or euthanasia by the elderly. The fundamental reason was the condition of health and physical pain as well as mental illnesses, but the direct motive associated with old age was taedium vitae - weariness of life.

${ }^{81}$ Livius, Ab Urbe condita księga 120, 50, w: Seneca Maior, Suasoriae 6, 17; por. Everitt, Cicero, s. 298-299. 
